ZalǫcZnilf

DOI 10.21697/zk.2020.7.08

\title{
AUDIOWIZUALNE ZAWROTY GŁOWY. ALFRED HITCHCOCK I WIDEOESEJE
}

PAWEt BILIŃSKI

Wydział Filologiczny UG

Faculty of Languages, University of Gdańsk

powetbiliziki@wp.pl

ORCID: 0000-0002-4724-4542

Współczesny badacz pragnący zajmować się naukowo twórczością Alfreda Hitchcocka stoi przed nie lada wyzwaniem związanym z obowiązkiem zapoznania się z imponującą liczbą rozmaitych publikacji poświęconych autorowi Zawrotu głowy (Vertigo, 1958): odsłaniającymi kulisy produkcji szkicami historycznofilmowymi, tekstami interpretującymi poszczególne dzieła przez pryzmat psychoanalizy czy pogłębionymi analizami filmów, które niejednokrotnie doczekiwały się oddzielnych i, zdawałoby się, wyczerpujących problematykę fascynujących książek. Potężny korpus studiów badawczych stale się jednak rozrasta i nic nie wskazuje na to, by kino Hitchcocka miało zostać zaniedbane przez kolejne pokolenia odbiorców. Nieustannie pojawiają się preteksty, by do filmów reżysera wracać: czy to przy okazji wyróżnienia wspomnianego wyżej dzieła w rankingu brytyjskiego magazynu „Sight \& Sound” w 2012 roku, czy to w celu uczczenia kolejnych rocznic premier ważniejszych pozycji z filmografii lub też obchodów jubileuszu urodzonego przed 120 laty reżysera.

W XXI wieku mamy do czynienia z coraz większym zróżnicowaniem studiów poświęconych Hitchcockowi. Do listy artykułów i książek skoncentrowanych na twórczości i życiu brytyjskiego reżysera dopisać wypada rozmaite teksty audiowizualne - zwłaszcza umieszczane na rozmaitych platformach internetowych wideoeseje, których autorzy coraz chętniej koncentrują swoją uwagę na dziełach i biografii autora Psychozy (Psycho, 1960).

W niniejszym szkicu chciałbym skupić się właśnie na tej grupie utworów, które w bardzo ciekawy i wieloaspektowy sposób uzupełniają tradycyjne teksty badawcze, a które dotychczas nie były opisywane w piśmiennictwie filmoznawczym. Charakterystyka krótkich form audiowizualnych poświęconych Hitchcockowi pozwoli nie tylko uzupełnić dotychczasowy stan 
badań, ale pomoże też, mam nadzieję, zwrócić uwagę na prężny rozwój samej wideoeseistyki.

\section{FENOMEN (NIE TYLKO) Z YOUTUBE'A}

Choć utwory, które dziś moglibyśmy określić mianem wideoesejów, powstają od wielu lat ${ }^{1}$, to momentem przełomowym dla rozwoju tej formy twórczości był początek XXI wieku. To wówczas pojawiły się platformy Vimeo (2004) i YouTube (2005), na których sukcesywnie zaczęto publikować różnego rodzaju filmiki, zmontowane nie tylko przez profesjonalistów (oba serwisy stały się naturalnym miejscem dla wideoklipów muzycznych), ale również przez amatorów pragnących podzielić się swoją twórczością ${ }^{2}$. „Obrośnięcie” kolejnych tekstów kultury, w tym filmów powstałych przed kilkudziesięciu laty, w różnorodne parateksty stało się więc kwestią czasu. Już dekadę temu pisała o tym Iwona Kurz:

Można by sądzić, że serwis YouTube przyciąga wielu miłośników filmu; liczne spośród zamieszczonych w nim wypowiedzi mają charakter cytatów i odniesień do istniejących dzieł filmowych lub rozmaitych montaży, przeróbek, odegrań i powtórzeń znanych scen i sekwencji. Jest zatem ten serwis polem, celem (i efektem) rozmaitych praktyk nadawczo-odbiorczych, w pewnym sensie także kolekcjonerskich, związanych z filmem³ .

1 Za jeden z pierwszych tego typu utworów uznaje się powstały w 1992 film Rock Hudson's Home Movies Marka Rappaporta, do którego niejednokrotnie odnosił się Kevin B. Lee, jeden z czołowych wideoeseistów. Zob. P. Biliński, Palimpsesty. Wideoeseistyka Kevina B. Lee, „EKRANy” 2016, nr 5 (33), s. 15.

2 O znaczeniu kultury uczestnictwa w kontekście platformy YouTube pisali Jean Burgess i Joshua Green: „Dyskurs [YouTube'a] [...] zachęca nas do wyobrażenia sobie jako idealnego partycypanta postaci szczególnego rodzaju: zwyczajnego amatora, motywowanego albo pragnieniem osobistej ekspresji, albo przez wspólnotę; amatora produkującego treści, które wyrażają to, co prozaiczne czy codzienne [...] lub pokazują wysoki poziom kreatywności i walorów rozrywkowych"; J. Burgess, J. Green, Przedsiębiorczy Vloger: kultura uczestnictwa poza podziałem na profesjonalistów i amatorów, tłum. D. Rode, [w:] Badanie widowni filmowej. Antologia przekładów, red. K. Klejs, M. Saryusz-Wolska, Warszawa 2014, s. 387.

3 I. Kurz, "I got you tube”. Kino a serwis YouTube.com - odmiany kinofilii, [w:] Pogranicza audiowizualności. Parateksty kina, telewizji i nowych mediów, red. A. Gwóźdź, Kraków [cop. 2010], s. 417. 
Nieskończenie pojemne serwery YouTube i Vimeo stały się więc internetową przestrzenią, w ramach której każdy, jeśli tylko odczuwa taką potrzebę, może na swój sposób skomentować dany utwór audiowizualny swoim utworem audiowizualnym - bodaj jedyną negatywną dla użytkownika konsekwencją może być usunięcie jego lub jej dzieła z portalu ze względu na nieposzanowanie praw autorskich wynikające ze zbytniej ingerencji w oryginalny film.

Szeroki zakres możliwości manipulowania materiałem filmowym dzięki łatwemu dostępowi do różnych programów służących edycji wideo w rodzaju Final Cut Pro - miał niewątpliwy wpływ na zmianę praktyk odbiorczych. Ewoluujący od kilkudziesięciu lat kontakt z kinem, w którym odbiorca mógł coraz głębiej wniknąć w interesujący go audiowizualny tekst (rozpoczęty na dobre dzięki popularyzacji nośnika VHS), wszedł zatem w kolejny etap. Realizacja wideoesejów, będących swoistą formą osobistego kinopisania, była więc, jak się wydaje, kwestią czasu.

Opisywany sposób komentowania i reinterpretowania filmów $w^{4}$ jest zjawiskiem fascynującym, bo niełatwym do zaklasyfikowania. Wideoeseistyka pozostaje w równej mierze elementem akademickiego filmoznawstwa, szeroko pojętej krytyki i publicystyki filmowej ${ }^{5}$, ale też może być odbierana jako skuteczne narzędzie popularyzatorskie. Stanowi przykład myślenia za pomocą obrazu, jak też swoistego widzenia „za pomocą obrazów wcześniej podpatrzonych, zapamiętanych albo po prostu zarejestrowanych i gotowych do odtworzenia"'. Autorzy tych form - a nie brakuje wśród nich

${ }^{4}$ Choć, trzeba zaznaczyć, realizujący wideoeseje nie zawsze muszą koncentrować swoją uwagę na kinie. Coraz więcej w sieci można znaleźć podobnych dzieł traktujących o świecie gier wideo - nie tylko niezwykle popularnych wideorecenzji, ale też ambitnych eseistycznych form, za pomocą których użytkownicy opisują historię, teorię i praktykę gier wideo.

5 "Rozróżnienie między naukowym a nienaukowym pisaniem o kinie jest dziś znacznie mniej trwałe, aniżeli w ostatnich dekadach" - pisał przed paroma laty w swoim szkicu o wideoesejach Christian Keathley; Ch. Keathley, La Caméra-Stylo. Notes on Video Criticism and Cinephilia, [w:] The Language and Style of Film Criticism, eds. A. Clayton, A. Klevan, London - New York, 2011, s. 177.

${ }^{6}$ G. Świętochowska, Wideoesej, czyli od Chrisa Markera do Fandoru. Historia awansu pewnej formy audiowizualnej wyrosłej z kinofilii, „Kwartalnik Filmowy” 
osób uznawanych dziś za mistrzów gatunku - korzystają z różnorodnych metod remiksowania i odnoszenia się do gotowych filmów. Ta wielość możliwości, łatwy dostęp do narzędzi, wreszcie chęć tworzenia oryginalnych komentarzy do filmów (lub zjawisk z historii kina) sprawiły, że wideoeseistyka w ostatnich latach stała się zjawiskiem nie tylko fascynującym, ale też niejednokrotnie trudnym do uchwycenia pod względem poznawczym (barierą może być na przykład język, którym przemawiają „z offu” twórcy wideoesejów). W uporządkowaniu pomagają więc strony internetowe poświęcone podobnym tekstom kultury (vide prowadzone przez Catherine Grant „Audiovisualcy. An Online Forum for Videographic Film Studies”7), naukowe periodyki (wśród nich za najważniejszy uchodzi „[In]Transition. Journal of Videographic Film \& Moving Image Studies”») oraz różnego rodzaju rankingi zestawiające najważniejsze dokonania w zakresie wideoeseistyki ostatnich miesięcy (największym wkładem w tym zakresie może pochwalić się „Sight \& Sound”9). Zwracam na to uwagę, bo dzięki tego rodzaju platformom możemy z większą dokładnością ustalić, na jakich tematach najczęściej koncentrują swoją uwagę montujący wideoeseje - wśród nich, rzecz jasna, także ci, którzy zdecydowali się montować dzieła związane z Hitchcockiem i jego filmami.

Powyższa krótka charakterystyka języka i historii tej młodej formy wypowiedzi artystyczno-naukowo-badawczej ma na celu pomóc nam

2018, nr 104, s. 7. Warto zauważyć - o czym także pisze autorka - że źródeł tych wideoeseistycznych wypowiedzi należy doszukiwać się w ewolucji eseju filmowego, o którym Świętochowska wspomina w części tekstu znamiennie zatytułowanej $Z$ archeologii wideoeseju. Sam namysł teoretyczny nad tego rodzaju praktyką niejako sprzężony jest z przeżywającymi ostatnio rozkwit badaniami nad esejem filmowym jako takim. Zob. T. Corrigan, The Essay Film: From Montaigne, After Marker, Oxford - New York 2011; Essays on the Essay Film, eds. N.M. Alter, T. Corrigan, New York 2017; N.M. Alter, The Essay Film After Fact and Fiction, New York 2018.

7 Zob. https://vimeo.com/groups/audiovisualcy [dostęp 15.01.2020].

8 Publikowany, z oczywistych względów, jedynie online: http://mediacommons.org/intransition/ [dostęp 15.01.2020].

9 Zob. A. Avissar, W. DiGravio, G. Lee, The Best Video Essays of 2019, https:// www.bfi.org.uk/news-opinion/sight-sound-magazine/polls-surveys/best-video-essays-2019 [dostęp 15.01.2020]. 
w swobodnym poruszaniu się po wirtualnym świecie, w którym liczba wideoesejów (także tych o Hitchcocku) z dnia na dzień rośnie coraz szybciej.

\section{WIDEOESEISTYKA I HITCHCOCK: PROLOG}

Zanim przejdziemy do charakterystyki interesującego nas zagadnienia, warto na wstępie zaznaczyć, że o historii hitchcockowskich paratekstów - a wideoeseje o Hitchcocku i jego twórczości także się do tychże zaliczają - z pewnością można by napisać książkę. Mało który reżyser, zwłaszcza spośród tych reprezentujących epokę kina klasycznego, może być uznany za prawdziwą gwiazdę - to miano zwykle rezerwowano dla aktorów. Tymczasem autor Zawrotu głowy jeszcze za życia stał się pierwszoplanową postacią telewizyjnej serii, gdzie w roli charakterystycznego gospodarza zapraszał widzów do obejrzenia kolejnego kryminału - już same introdukcje do poszczególnych odcinków moglibyśmy potraktować jako osobne teksty kultury. Ponadto - i co może istotniejsze w kontekście interesującego nas tematu - Hitchcock występował w zwiastunach do swoich filmów. Zwiastunach, dodajmy, niejednokrotnie będących krótkometrażowymi majstersztykami, w których w niekonwencjonalny sposób starano się zachęcić widzów do uczestniczenia w zbliżającej się premierze filmu ${ }^{10}$. Zwracam na powyższe aspekty uwagę, bo wydaje się, że na liczbę wideoesejów traktujących o Hitchcocku i jego filmach wpływ ma nie tylko jakość i popularność poszczególnych dzieł sygnowanych nazwiskiem reżysera, ale też rozpoznawalność twórcy, w dużej mierze wynikająca ze znakomitego wyczucia w kwestii autokreacji, czemu również pomogły regularne ekranowe występy reżysera we własnych filmach.

Za swoistą prolegomenę do wideoeseistycznego namysłu nad Hitchcockiem i jego utworami można uznać wydarzenie opisywane przez François Truffauta w rozmowie-rzece:

Kiedy chcę zapomnieć Hitchcocka z okresu upadku, cofam się myślą o sześć lat, konkretnie - do wieczoru 29 kwietnia 1974 w Lincoln Center, gdzie

${ }^{10}$ Bodaj najsłynniejszy pozostaje trailer do Psychozy, w którym Hitchcock oprowadza widzów po Bates Hotel, gdzie - jak sam informuje - dokonała się straszna zbrodnia. Zob. https://www.youtube.com/watch?v=AJdPFYENJBo [dostęp 31.12.2019]. 
Nowojorskie Towarzystwo Filmowe zorganizowało na jego cześć doroczną galę. To był prawdziwie inspirujący wieczór. W ciągu trzygodzinnego spektaklu można było obejrzeć sto fragmentów jego filmów, wszystkie owe „brawurowe kawałki”, pogrupowane w osobnych blokach: „Kamee” (osobiste pojawienia się Hitchcocka w swoich filmach), „Pogonie”, „Źli chłopcy”, „Zbrodnie”, „Sceny miłosne” oraz dwie wielkie sceny w całości [...].

Tego wieczoru, po obejrzeniu wszystkich tych znanych na pamięć, ale odłączonych od swojego kontekstu fragmentów, uderzyła mnie szczerość, a równocześnie dzikość dzieła Hitchcocka. Nie można było nie zauważyć, że wszystkie sceny miłosne były filmowane jak sceny zbrodni, a wszystkie sceny zbrodni - jak sceny miłosne. Znałem tę twórczość, uważałem nawet, że znam ją bardzo dobrze, a jednak to, co zobaczyłem, oszołomiło mnie ${ }^{11}$.

W powyższym fragmencie rozmowy-rzeki zwracają uwagę zwłaszcza wspomniane przez Truffauta minifilmy, wyliczające i porządkujące charakterystyczne dla obrazów Hitchcocka motywy, a wśród nich ten, do którego po wielu latach wracać będą twórcy krótkich filmików w Internecie: mające niejednokrotnie komediowy charakter reżyserskie cameos. Zatem pochodzący sprzed kilkudziesięciu lat swoisty supercut w pewien sposób wydaje się proroczy, bo zwiastujący potrzebę wskazywania i porządkowania wizualno-tematycznych dominant twórczości autora Zawrotu głowy. Internetowe platformy umożliwiające komunikowanie się za pomocą mniej lub bardziej amatorsko montowanych tekstów audiowizualnych okazały się idealną przestrzenią do dzielenia się tego rodzaju spostrzeżeniami. Poświęcone Hitchcockowi prace nade wszystko potwierdzają niesłabnącą potrzebę namysłu nad biografią i filmografią brytyjskiego reżysera, które można za każdym razem opisywać, przyjmując odmienną perspektywę.

Trzeba zaznaczyć, że na samo wyliczenie wideoesejów o Hitchcocku potrzebny byłby osobny szkic - nie sposób nawet dotrzeć do wszystkich filmików znajdujących się w przepastnych archiwach Internetu. Dlatego też chciałbym skupić uwagę na reprezentatywnej grupie kilkudziesięciu krótszych (począwszy od trwających około minuty) czy dłuższych (do trwających przeszło 40 minut) audiowizualnych prac. Próbując ustalić najważniejsze różnice pomiędzy wideoesejami sytuującymi w centrum życie lub

${ }^{11}$ F. Truffaut, Hitchcock / Truffaut, współpraca H. Scott, tłum., oprac. i posłowie T. Lubelski, Izabelin 2005, s. 328. 
twórczość Hitchcocka, zdecydowałem się na następujący podział, wynikający z charakteru poszczególnych utworów i tematyki, na jakiej koncentrują się ich twórcy: po pierwsze są to wideoeseje zestawiające wychwycone przez autorów motywy z filmów Hitchcocka, po drugie - audiowizualne teksty traktujące o metodzie reżysera, po trzecie - krótkie filmy o wpływie dzieł Brytyjczyka, po czwarte - próby analiz wybranych filmów reżysera, po piąte - wideoeseje, których autorzy mają ambicje interpretować dzieła Hitchcocka w perspektywie historycznofilmowej, wreszcie po szóste - różnorodne remiksy, opierające się najczęściej na montowaniu fragmentów filmów Hitchcocka z ujęciami pochodzącymi z innych tekstów kultury. Poniższe zestawienie pozwoli ustalić, na czym najczęściej koncentrują swoją uwagę autorzy wideoesejów. Autorzy, dodajmy, zafascynowani nie tylko twórczością reżysera Psychozy, ale też samą formą, za pomocą której mogą o tej twórczości mówić.

\section{OCZY, DŁONIE, UPADKI}

Zacytowany wyżej Truffaut w swoim wspomnieniu pisał o prezentowanych na dużym ekranie „pogoniach”, „zbrodniach”, „scenach miłosnych” - sekwencjach zmontowanych w krótkie filmiki mające uwypuklić tematyczno-wizualno elementy, które w różnych wariantach refrenowo wracały w poszczególnych filmach Hitchcocka. Nawet pozbawione komentarza „z offu” tego typu prace stawiały wyraźnie zaznaczoną tezę, że oto mamy do czynienia $\mathrm{z}$ realizatorem świadomie korzystającym ze sprawdzonych konwencji gatunkowych i kładącym nacisk na uwypuklenie komponentów rozpoznawalnych dla widza zaznajomionego $\mathrm{z}$ innymi dziełami reżysera. Tendencja, by za pomocą wideoesejów wskazywać elementy mogące potwierdzić autorskie podejście danego twórcy do kształtowania światów przedstawionych, od pewnego czasu jest jednym z dominujących tematów „wideopisania” o kinie. Nie inaczej jest w przypadku Hitchcocka, którego występy na ekranie - jak już wspomniałem - doczekały się podobnych prac zestawiających cameos: zwykle prezentujących ujęcia z Hitchcockiem chronologicznie, więc od podwójnej roli w Lokatorze (The Lodger - A Story of the London Fog, 1927) do ironicznego finału w postaci Intrygi rodzinnej 
(Family Plot, 1976), gdzie Brytyjczyk zagrał pracownika biura rejestrującego narodziny i zgony ${ }^{12}$.

Powstało jednak wiele innych, znacznie oryginalniejszych wideoesejów wyliczających co bardziej charakterystyczne estetyczno-narracyjne motywy i chwyty w twórczości Hitchcocka. Jednym z nich jest The Hitchcock Gallery ${ }^{13}$ (2014) Stevena Benedicta, którego autor, montując fragmenty z czterdziestu różnych filmów, wskazuje powtarzające się w nich lejtmotywy (bohaterowie wchodzący po schodach, rozsuwane kotary, postaci spadające z wysokości), sposoby inscenizowania (protagoniści patrzący w stronę kamery) czy nawet fryzury (głównie dotyczy to aktorek o blond włosach). Pozbawiony głosu narratora, ilustrowany charakterystycznym motywem muzycznym Bernarda Herrmanna z Zawrotu głowy wideoesej Benedicta można potraktować jako reprezentacyjny dla opisywanej grupy - o ile tutaj mamy brawurową próbę cytującą większość filmów Hitchcocka, o tyle w kolejnych autorzy koncentrują się na wybranym przez siebie wątku, niejednokrotnie przywołując te same sceny, które wskazywał Benedict.

Jednym z popularniejszych tego typu wideoesejów pozostaje Eyes of Hitch cock ${ }^{14}$ (2014), zmontowany dla prestiżowego wydawnictwa Criterion Collection przez uznanego użytkownika podpisującego swoje prace jako „kogonada”. W tym trwającym niespełna dwie minuty krótkim metrażu zestawione zostają ujęcia Hitchcockowskich bohaterów patrzących w kierunku widza. Kogonada nie bierze pod uwagę wszystkich filmów brytyjskiego reżysera, jednak mimo ograniczenia się do najpopularniejszych arcydzieł - obok legendarnego ujęcia Normana Batesa z finału Psychozy czy momentu, w którym Lila Crane widzi atakującą ją postać z nożem, oglądamy Rogera Thornhilla z Północ, północny zachód (North by Northwest 1959), z lękiem patrzącego na nadlatujący samolot, czy twarz przerażonego Scottiego Fergusona budzącego się po koszmarze - udaje mu się dowieść,

${ }_{12}$ Zob. klip Every Alfred Hitchcock Cameo, zmontowany przez Morgana T. Rhysa; https://www.youtube.com/watch?v=_YbaOkiMiRQ [dostęp 15.01.2020].

13 Zob. https://vimeo.com/115718613 [dostęp 15.01.2020].

14 Do początku 2020 roku wspomniany wideoesej został odtworzony niemal 400 tys. razy, a trzeba zaznaczyć, że ten sam klip umieszczano również z innych, nieoficjalnych kont. Zob. https://vimeo.com/107270525 [dostęp 15.01.2020]. 
jak duży nacisk Hitchcock kładł na inscenizowanie ujęć, w których przede wszystkim zwracamy uwagę na oczy protagonistów.

$\mathrm{Z}$ pracą kogonady korespondują dwa wideoeseje przygotowane przez Jorge Luengo Ruiza. Pierwszy z nich, Alfred Hitchcock's Close-Ups ${ }^{15}$ (2015), koncentruje się na zestawieniu najbardziej znaczących dla fabuł poszczególnych filmów najazdów, zbliżeń i prezentacji detali. Podobny doń jest powstały dwa lata później Alfred Hitchcock // Point of View ${ }^{16}$, gdzie Ruiz posłużył się techniką split screen, z lewej strony ekranu umieszczając ujęcia bohaterów, z prawej zaś obiekty lub osoby, na które ci protagoniści patrzą. Oba szkice pozbawione są komentarza $\mathrm{z}$ offu, zapraszając tym samym odbiorców do własnej interpretacji Hitchcockowskich motywów. Szczególnie interesujący jest pierwszy film, w którym przede wszystkim zwraca uwagę predylekcja brytyjskiego reżysera do pokazywania dłoni przekazujących klucze oraz zbliżeń na książki, z których można wyczytać informacje szczególnie istotne dla intrygi dzieła (gdy tekstu lub liczb jest zbyt wiele, nieodzowna staje się pomoc palców wskazujących to, co najważniejsze).

Z drugim wideoesejem Ruiza koresponduje praca Matta Novaka, który w Hitchcock's Hands ${ }^{17}$ (2017) na kilku przykładach przedstawił sposoby prezentacji dłoni bohaterów - od ujęć pochodzących z Szantażu (Blackmail, 1929), gdzie widzieliśmy bohaterkę, która po morderstwie niepewnie sięga po nóż do krojenia chleba, do finału sceny pod prysznicem z Psychozy, kiedy Marion Crane w ostatnich momentach życia chwyta się zasłony. Warto zauważyć, że Hitchcock's Hands został zmontowany dla platformy Fandor, która swego czasu mocno inwestowała w realizację i promocję wideoesejów. Dla tej strony internetowej powstał także ironiczny The Hitchcock Trademark No One Talks About ${ }^{18}$ (2017). Jego autor, Bill Rwehera, zwraca uwagę na powtarzalność motywu spadających czy zrzucanych z wysokości bohaterów z poszczególnych filmów Hitchcocka (są tu cytaty między innymi z Sabotażu [Saboteur, 1942], Okna na podwórze [Rear Window, 1954] i Złodzieja w hotelu [To Catch a Thief, 1955]). Żartobliwość audiowizualnego szkicu podkreśla kilkunastosekundowy prolog, w którym autor uwypukla

15 Zob. https://vimeo.com/137761623 [dostęp 15.01.2020].

16 Zob. https://vimeo.com/211361198 [dostęp 15.01.2020].

17 Zob. https://vimeo.com/230194725 [dostęp 15.01.2020].

18 Zob. https://www.youtube.com/watch?v=JVoiI-wCNm8 [dostęp 15.01.2020]. 
inne charakterystyczne dla dzieł Hitchcocka komponenty: choćby omawiane już występy reżysera w swoich filmach czy skłonność do portretowania kobiet o blond włosach - z pewnością częściej wspominane aniżeli motyw spadania. Spostrzeżenie Rwehery jest jednak o tyle trafne, że uargumentowane cytatami z dzieł Hitchcocka potwierdzającymi zasadność postawionej tezy.

Spośród podobnych wideoesejów zwraca jeszcze uwagę Alfred Hitchcock's 39 Stairs $^{19}$ (2017) Maxa Tohline’a, gdzie zacytowano ujęcia bohaterów schodzących i wchodzących po schodach. Tohline swoją pracę opatrzył adnotacją znajdującą się pod filmem, w której zwrócił uwagę na próby opisu motywu schodów w wideoesejach powstałych wcześniej (odwołał się do Stairs to Suspense: An Alfred Hitchcock Montage z 2012 roku), jednak w żadnym $\mathrm{z}$ nich nie zostało to scharakteryzowane na tylu przykładach - Tohline zacytował bowiem sceny pochodzące z trzydziestu dziewięciu filmów Hitchcocka, co uwypuklone zostało w tytule nawiązującym do 39 kroków (39 Steps, 1935).

\section{STUDIA NAD METODA}

W przeciwieństwie do wideoesejów zestawiających powtarzające się motywy, te traktujące o warsztacie reżyserskim i technikach narracyjnych Hitchcocka w większości opatrzone są komentarzem „z offu”, wygłaszanym przez samych autorów drobiazgowo analizujących sposób opowiadania filmów brytyjskiego twórcy. Materiał wizualny i muzykę opisywanych dzieł uzupełniają oni o napisaną przez siebie narrację, wzbogacając tym samym przekaz. Trzeba jednak zauważyć, że propozycje interpretacyjne autorów choć niejednokrotnie przedstawiane w sposób więcej niż tylko intrygujący nieczęsto można by określić mianem szczególnie oryginalnych. Jednak dzięki połączeniu głosu „z offu” z odpowiednio dobranym materiałem audiowizualnym mamy do czynienia $z$ atrakcyjnymi utworami mogącymi funkcjonować na polu popularyzatorskim.

Jednym z tego typu przekonująco zmontowanych wideoesejów jest How Hitchcock Creates Suspense ${ }^{20}$ (2017), w którym użytkownik Entertain the Elk stara się odpowiedzieć na postawione w tytule pytanie, posiłkując

\footnotetext{
19 Zob. https://vimeo.com/239872105 [dostęp 15.01.2020].

20 Zob. https://www.youtube.com/watch?v=s-QVHJDmD6A [dostęp
} 15.01.2020]. 
się analizą sceny z Ptaków (The Birds, 1963). Scena ta przedstawia Melanie, główną bohaterkę, $\mathrm{w}$ trakcie palenia papierosów na podwórzu, kiedy to na znajdującym się za jej plecami trzepaku zbierają się ptaki, o których wiemy z wcześniejszych scen, że zagrażają bezpieczeństwu ludzi. Entertain the Elk zwraca uwagę i na długość kolejnych ujęć (kolejno: Melanie patrzącej w zamyśleniu w przestrzeń i przysiadających na trzepaku zwierząt), i na słyszany „Z offu” śpiew dzieci. Ponadto autor cytuje w wideoeseju rozmowę, w której Hitchcock opisuje, czym dla niego jest suspens i jak odróżnić go od szoku. W trakcie wykładu brytyjskiego reżysera widz ogląda sceny przedstawiające nagły wybuch bomby w filmie Ludzkie dzieci (Children of Men, 2006) Alfonsa Cuaróna oraz długie ujęcie inicjujące akcję Dotyku zła (Touch of Evil, 1958) Orsona Wellesa, w którym mamy do czynienia z modelową dla suspensu sytuacją - widz od początku wie, że w samochodzie została podłożona bomba, zaczyna się więc niepokoić o życie niczego nieświadomych protagonistów jadących pojazdem zawierającym ładunek wybuchowy.

Znamienne, że do sceny z Ludzkich dzieci odwołuje się także autor kanału This Guy Edits, kiedy opisuje trzy najważniejsze, jego zdaniem, techniki narracyjne filmów Hitchcocka ${ }^{21}$, z których jedną jest oczywiście suspens. Pozostałe to przekazywanie informacji o postaciach czy świecie przedstawionym bez użycia dialogów (użytkownik określa to jako pure cinema [ang. czyste kino] i jako przykład podaje pierwszą sekwencję z Okna na podwórze) oraz unikanie wprowadzania nagłych, wynikających z przypadku, zwrotów akcji.

Autor podpisujący swoje prace jako The Discarded Image w How Alfred Hitchcock Manipulates An Audience ${ }^{22}$ (2016) koncentruje się na sposobach kierowania emocjami widza w trakcie projekcji Psychozy - filmu, w którym w pierwszej części trzymamy stronę osoby kradnącej pieniądze (wybaczamy Marion głównie dlatego, że właściciel gotówki nie zostaje przedstawiony jako postać pozytywna), w drugiej zaś sympatyzujemy z rzekomo działającym pod wpływem despotycznej matki Normanem Batesem - i to nawet mimo tego, że pozbywa się on ciała zamordowanej Marion.

${ }^{21} 3$ Hitchcock Techniques We Should Copy More; https://www.youtube.com/ watch?v=E1LzhiCcOY0 [dostęp 15.01.2020].

${ }^{22}$ Zob. https://www.youtube.com/watch?v=xm-9E275D9c [dostęp 15.01.2020]. 
Na tle powyższych najsilniej wyróżnia się How Alfred Hitchcock Blocks a Scene $e^{23}$ (2016) - brawurowa analiza jednej sceny pochodzącej z Zawrotu głowy. Autor wideoeseju, podpisujący się jako Nerdwriterl, przygląda się sekwencji rozmowy Scottiego i Galvina Elstera, kiedy ten drugi chce zlecić przyjacielowi śledzenie swojej żony. Nerdwriterl, podkreślając znaczenie tej sceny w kontekście całej fabuły (dopiero przy drugiej projekcji orientujemy się, że Galvin w rzeczywistości manipuluje Scottiem), w obrębie jednego kadru umieszcza ujęcia z filmu i sporządzaną przez siebie grafikę wyraźnie wskazującą, w jaki sposób poruszają się po pomieszczeniu protagoniści i który z nich jest osobą dominującą. Zdaniem autora wideoeseju tak zainscenizowana scena w dużym stopniu zapowiada tematykę filmu - tak jak Zawrót głowy odnosi się do voyeuryzmu i konstrukcji podmiotu, tak w opisywanym fragmencie Scottie jest sterowaną kukiełką w spektaklu, który obmyśla dlań Galvin.

\section{HITCHCOCK I INNI}

Wątek wpływu estetyki i narracji filmów Hitchcocka na kino jest jednym z częściej rozpatrywanych przez wideoeseistów. Możliwości manipulowania obrazem w opisywanych tekstach kultury wydaje się sprzyjać tego rodzaju refleksji. Potwierdzeniem tego jest choćby Hitchcock \& De Palma Split Screen Bloodbath ${ }^{24}$ (2016), w którym Peet Gelderblom na ekranie zestawia sceny z filmów Brytyjczyka z fragmentami dzieł autora Wybuchu (Blow Out, 1981), który znany jest z eksplicytnego zaznaczania cytatów filmowych. Inwencja Gelderbloma w dużej mierze wynika z faktu, że gdy na lewej stronie ekranu pokazuje on wyłącznie scenę "prysznicową" z Psychozy, to z prawej widz ogląda skrupulatnie zmontowany klip cytujący jedenaście filmów De Palmy - od Sióstr (Sisters, 1972) do Namiętności (Passion, 2012). I we wszystkich tych dziełach, jak udało się dowieść Gelderblomowi, można znaleźć czytelne odwołania do sceny pochodzącej z filmu z 1960 roku.

Metodą split screenu posłużył się także Leigh Singer w Psycho vs Psycho. Alfred Hitchcock's Original vs Gus Van Sant's Remake 25 (2019), gdzie doko-

${ }^{23}$ Zob. https://www.youtube.com/watch?v=UgnNakO6JZw [dostęp 15.01.2020].

${ }_{24}$ Zob. https://vimeo.com/193068848 [dostęp 15.01.2020].

25 Zob.https://www.youtube.com/watch?v=xI_4LT7BTm4\&feature=emb_logo [dostęp 15.01.2020]. 
nano zestawienia podobnych ujęć z dwóch filmów wskazanych w tytule wideoeseju. Singer nie ogranicza się jednak do analizy porównawczej zwraca także uwagę na inne teksty kultury, które nawiązywały do słynnej sceny rozgrywającej się pod prysznicem (wśród wymienianych przezeń dzieł jest serial Simpsonowie). Najważniejszym celem wideoeseju pozostaje jednak wskazywanie różnic między Psychozq a Psycholem (Psycho, 1998) czy to pod względem metrażu (film Van Santa jest krótszy o nieco ponad 10 minut), dokonanych skrótów i zmian (vide zestawienie kadrów z obu filmów pokazujące, ile dokonano cięć w scenie morderstwa Marion Crane), wreszcie: sportretowania bohaterów różniących się pod względem charakterów (Lila Crane w interpretacji Julianne Moore jest o wiele bardziej zaradna i zdecydowana od tej samej bohaterki granej wcześniej przez Verę Miles).

Wpływ innego filmu Hitchcocka opisuje Mr Nerdista w ROPE: How Alfred Hitchcock Changed Editing Forever ${ }^{26}$ (2017), w którym analizę Sznura (Rope, 1948) - filmu złożonego z bardzo długich ujęć i w sprytny sposób maskującego cięcia między nimi - uzupełnia wspomnienie kilku wybranych przez autora dzieł (wymienione zostają choćby Birdman [2014] czy Creed: Narodziny legendy [Creed, 2015]), pod względem montażu wiele zawdzięczających oryginalnej koncepcji Hitchcocka. Z kolei w zrealizowanym dla serwisu Fandor wideoeseju The Influence of „Vertigo”27 (2018) Jacob T. Swinney krótko tłumaczy fenomen Zawrotu głowy i jego wpływ na współczesne kino. Narracji „Z offu” wtórują cytaty z filmu dokumentalnego Hitchcock/Truffaut (2015) Kenta Jonesa, w którym wystąpili różni reżyserzy pochylający się nad ponadczasowością dzieła z 1958 roku. Krótki metraż (mniej niż 4 minuty) eseju Swinneya nie pozwala skomentować ciekawych zestawień - autor w obrębie kadru umieszcza fragment Zawrotu głowy oraz innego filmu, który doń nawiązywał. Szkoda tym większa, że dobór współczesnych utworów - między innymi: Toy Story 2 (1999), Wyspa tajemnic (Shutter Island, 2010) czy Skyfall (2012) - jest nieoczywisty.

Wreszcie autor jednego z wideoesejów poszukuje śladu wpływów twórczości Hitchcocka w filmach autora 400 batów (Les quatre cents coups,

26 Zob. https://www.youtube.com/watch?v=W8R5Kd4NWKM [dostęp 15.01.2020].

27 Zob.https://www.youtube.com/watch?v=F3WHuOcwyUs [dostęp 15.01.2020]. 
1959). W Hitchcock|Truffaut ${ }^{28}$ (2016) Brais Romero przywołuje trzy dzieła francuskiego reżysera - Pannę młoda $w$ żałobie (1968), Kobietę $z$ sąsiedztwa (La femme d'à côté, 1981) oraz Byle do niedzieli (Vivement dimanche!, 1983) - i znajduje w nich sceny pod względem inscenizacyjnym mające wiele wspólnego z ujęciami z dzieł Hitchcocka. Zestawienie fragmentów kolejnych sekwencji pochodzących z filmów obu autorów umożliwia potwierdzenie nieoczywistej tezy. Tezy, dodajmy, przedstawionej jedynie za pomocą obrazu, bo w Hitchcock|Truffaut montażysta nie odzywa się „Z offu”, zawierzając $\mathrm{w}$ pełni sugestywnym porównaniom sfer wizualnych dzieł Brytyjczyka i Francuza.

\section{„HITCHCOCK EXPLAINED”}

Czwartą grupę wideoesejów stanowią audiowizualne analizy wybranych filmów Hitchcocka. Trzeba zaznaczyć, że choć tych prac jest najwięcej - co wynika $\mathrm{z}$ chęci dzielenia się swoimi przemyśleniami na temat poszczególnych utworów - to ich autorzy niekoniecznie odnoszą się do dotychczasowych ustaleń. Ponadto niepodobna pominąć faktu, że gros spośród nich to interpretacje najsłynniejszych filmów brytyjskiego reżysera - trudno więc zliczyć wszystkie wideoeseje traktujące o Oknie na podwórze, Zawrocie głowy i Psychozie. Zwrócę więc uwagę jedynie na te, w moim odczuciu, najbardziej interesujące.

Przywoływany już wcześniej Bill Rwehera w The Many Genres of Rear Window ${ }^{29}$ (2017) rezygnuje z narracji „z offu”, montując swój szkic $\mathrm{z}$ fragmentów filmu Hitchcocka, na którego poszczególne ujęcia nałożone zostają odautorskie wtręty w postaci napisów. Rwehera podkreśla, że wielogatunkowość Okna na podwórze wynika stąd, że Jefferies widzi na przeciwległym budynku wiele okien - metaforycznych „ekranów” prowadzących do życia bohaterów, których historie (czy - jak to określa Rwehera - „mikronarracje”) można wiązać $\mathrm{z}$ różnymi gatunkami filmowymi: dramatem psychologicznym, horrorem, komedią erotyczną czy musicalem.

Wątek podglądania znajduje się w centrum zainteresowania Matta Drapera w Rear Window - Turning Viewer ino Voyeur ${ }^{30}$ (2017), w którym

\footnotetext{
28 Zob. https://vimeo.com/160927998 [dostęp 15.01.2020].

29 Zob. https://vimeo.com/229591018 [dostęp 15.01.2020].

30 Zob. https://www.youtube.com/watch?v=2UH10Mm-6tE [dostęp 15.01.2020].
} 
autor interpretuje film Hitchcocka przez pryzmat voyeurystycznych praktyk głównego bohatera skoncentrowanego na życiu sąsiadów, co skądinąd jest zgodne z jedną z najczęściej proponowanych interpretacji Okna na podwórze.

„Jefferies jest w takiej samej sytuacji, jak widownia filmu - może tylko siedzieć i patrzeć" - twierdzi autor kanału Jack's Movie Reviews w Rear Window - Hitchcock's Manipulation ${ }^{31}$ (2016), powtarzając tym samym to, co o Oknie na podwórze mówiło wielu przed nim. Ów wideoesej - we wstępie i w epilogu cytujący Hitchcocka, który miał niegdyś powiedzieć, że „lubi grać na emocjach widowni, tak jak się gra na fortepianie” - nade wszystko koncentruje się na strategiach reżysera manipulującego naszą perspektywą w filmie (vide analiza dialogu Jefferiesa z Doylem, zainscenizowanego i poprowadzonego w sposób faworyzujący optykę drugiego bohatera). Zrealizowane przez tego samego autora Vertigo Analysis - Love, Identity \& Relationships $^{32}$ (2017) ogniskuje się wokół relacji między bohaterami, co, zdaniem autora wideoeseju, jest szczególnie istotnym elementem Zawrotu głowy, bo też niewielu protagonistów tego dzieła zostaje nam bliżej przedstawionych. O ile prace umieszczone na kanale Jack's Movie Reviews dogłębnie opisują fabułę, to niewiele zawarto w nich analizy formalnej czy narracyjnej. Pod tym względem ciekawy jest wideoesej użytkownika podpisującego się jako „neo”, w którym autor pokusił się o charakterystykę kolorów użytych w Zawrocie głowy. Zwracając uwagę na przynależność danych kolorów do poszczególnych postaci (zieleń: Scottie, czerwień: Madeleine, żółć: Midge), twórca Vertigo - A Look at Color in Film ${ }^{33}$ (2016) uwypukla stronę wizualną jako wzbogacającą intrygę o kolejne znaczenia, co nie było często spotykane w kinie epoki klasycznej.

Sporo miejsca poświęca się, co nie jest zaskoczeniem, Psychozie. W Understanding Psycho: The Uncanny ${ }^{34}$ (2016) Margarita Georgitseas, autorka bloga ${ }^{35} \mathrm{i}$ kanału na YouTube nazwanego Is This Just Fantasy?, interpretuje film z 1960 roku w psychoanalitycznym kluczu, dostrzegając znamienne

31 Zob.https://www.youtube.com/watch?v=e4Yw8hz3tG8 [dostęp 15.01.2020].

32 Zob.https://www.youtube.com/watch?v=XjNZUXMsrgA [dostęp 15.01.2020].

${ }_{33}$ Zob. https://www.youtube.com/watch?v=scmHVYYZZ3w [dostęp 15.01.2020].

34 Zob.https://www.youtube.com/watch?v=_FMkGEZP3w0 [dostęp 15.01.2020].

35 Blog Is This Just Fantasy?; https://plainflavoredenglish.com [dostęp 15.01.2020]. 
podobieństwa między głównymi bohaterami noszącymi podobnie brzmiące imiona (Marion i Norman) i ukazywanymi wspólnie w przestrzeniach, w których znajdują się lustra. Understanding Psycho: The Uncanny na tle innych wideoesejów o Hitchcocku wyróżnia się solidnym naukowym „podglebiem” - Georgitseas w sposób przekonujący odnosi się do Freudowskiej teorii „niesamowitego” (unheimlich), cytuje między innymi prace Slavoja Žižka (i cytowany tekst pokazuje na ekranie), a pod klipem umieszcza krótką bibliografię. Sądząc po liczbie wyświetleń (ponad 300 tys. na początku 2020 roku), unaukowienie dyskursu nie przeszkodziło autorce w dotarciu do wielu odbiorców.

$\mathrm{O}$ wiele rzadziej wyświetlany jest pełen atrakcyjnych cytatów $\mathrm{z}$ audiowizualnych tekstów kultury (takich jak teledyski) Psycho and the Duality of $\mathrm{Man}^{36}$ (2018) Mackenziego Bella, w którym autor stara się obronić tezę, że Psychoza jest jednym z najlepszych dzieł traktujących o dualizmie człowieka. Zdaniem Bella Hitchcockowi do uwypuklenia wspomnianego tematu służą trzy rodzaje technik: bogata ścieżka dźwiękowa (na czele z wyróżniającą się muzyką), gra światłocieniem oraz przemyślane inscenizowanie postaci w obrębie kadru tak, by pozostawały usytuowane jako „symetrycznie przeciwstawione”. Zdawkowość wideoeseju i zwracająca na siebie uwagę faktura obrazu przypominająca jakość VHS nie pozwalają w pełni uzasadnić postawionej tezy, w efekcie czego ta bogata pod względem wizualnym i dźwiękowym praca pozostaje nazbyt szkicowa.

Na podwójności koncentruje swoją uwagę prowadzący kanał A Milion Moves, który w traktującym o Nieznajomych z pociagu (Strangers on a Train, 1951) eseju Strangers on a Train: The Doubles Motif ${ }^{37}$ (2018) wylicza wszelkiego rodzaju repetycje w zakresie inscenizacji czy powtórzenia zachowań bohaterów kojarzące się widzowi z wcześniejszymi scenami dzieła. Choć autor nie ma innego celu poza samym nagromadzeniem cytatów utwierdzających w przekonaniu, że Nieznajomi z pociągi nade wszystko bazują na wskazanym przez niego motywie, to już sama liczba ujęć potwierdzających zaproponowaną tezę może robić wrażenie.

${ }^{36}$ Zob. https://www.youtube.com/watch?v=UNACtHIeX-o [dostęp 15.01.2020].

37 Zob. https://www.youtube.com/watch?v=MW-IWM5CoQ4 [dostęp 15.01.2020]. 
Pośród wideoesejów analizujących wybrane dzieła Hitchcocka warto jeszcze wymienić Opening Choices - Notorious ${ }^{38}$ (2016), bodaj najbardziej "akademicki” film, nie tylko dlatego, że odpowiadają za niego John Gibbs i Douglas Pye, profesorowie uniwersytetu w Reading. Opening Choices to rzadki przypadek wideoeseju, w którym narracja „Z offu” zdaje się istotniejsza od warstwy obrazowej, na jaką złożyły się sceny z opisywanej przez autorów Osławionej (Notorious, 1946). Gibbs i Pye, bazując na licznych studiach historycznofilmowych (wideoesej zwieńczony jest kadrem z bibliografią), opisują, w jaki sposób ponowne zmontowanie sekwencji otwierającej film zmieniło charakter następujących po niej pozostałych partii dzieła.

Trzeba zaznaczyć, że wspomniane wideoeseje o Nieznajomych z pociagu czy Osławionej to nieliczne wyjątki spośród tych prac, które są próbami analiz innych filmów Hitchcocka niż Okno na podwórze, Zawrót głowy czy Psychoza. Choć pozostałe dzieła reżysera nie cieszą się aż taką estymą (a przynajmniej nie są na tyle inspirujące dla użytkowników, by montować o nich wideoeseje), pozostaje zapewne kwestią czasu, kiedy i one będą częściej opisywane w tego rodzaju audiowizualnych szkicach.

\section{HITCHCOCK I HISTORIA KINA}

Po obejrzeniu kilkudziesięciu wideoesejów związanych z Hitchcockiem widz nie będzie mieć wątpliwości - wątki historycznofilmowe nie są szczególnie często podejmowanym tematem przez autorów tego rodzaju tekstów kultury. O ile nietrudno (przynajmniej teoretycznie) podzielić się swoimi przemyśleniami na temat danego filmu Hitchcocka (czego potwierdzeniem są opisane wideoeseje), o tyle do postawienia jakiejkolwiek tezy z zakresu historii kinematografii potrzebna jest dogłębna znajomość historii kina, potwierdzona lekturą wielu książek czy artykułów.

Mimo powyższego warto wskazać kilka ambitnych prac, których autorzy pokusili się o usytuowanie dzieł Hitchcocka w innym kontekście aniżeli tym związanym $z$ analizą formalną czy interpretacją przez pryzmat psychoanalizy. Do takich z pewnością należy jeden z wideoesejów przygotowanych przez użytkownika prowadzącego kanał One Hundred Years of Cinema kanał, dodajmy, wsparty przez platformę streamingową MUBI, promującą

38 Zob. https://vimeo.com/185350060 [dostęp 15.01.2020]. 
światowe kino art-house'owe. One Hundred Years of Cinema, jak sama nazwa wskazuje, koncentruje się na wątkach związanych z historią kina - każdy odcinek przybliża kontekst danego roku i film będący szczególnie ważny dla czasu, w którym powstał. W 1940: Rebecca - Hitchcock's Obsessions... Love, Violence and the Psycho-Sexual ${ }^{39}$ (2018) autor przygląda się filmowi, od którego zaczęła się hollywoodzka kariera Brytyjczyka. Drobiazgowy opis fabuły Rebeki (Rebecca, 1940) jest jednak pretekstem, by spojrzeć na całą filmografię autora Szału (Frenzy, 1972) - reżysera od wczesnych lat ujawniającego fascynację blondynkami (czego potwierdzenie można znaleźć w Lokatorze) i łączącego organicznie tematykę erotyczną z namysłem na przemocą. W 1940: Rebecca - Hitchcock's Obsessions... zacytowane zostają, poza samą Rebeką, inne dzieła reżysera, w tym Zawrót głowy, którego jedna ze scen została opatrzona komentarzem w postaci mówiącego „z offu” Hitchcocka, analizującego poczynania Scottiego i jego stosunek do Judy.

Pod względem zebranych informacji i sposobu ich przekazania imponują dwa wideoeseje dotyczące procesu produkcji filmu Północ, północny zachód: The Bizarre Process of Writing „North by Northwest”| Screenwriting ${ }^{40}$ (2018) oraz How Hitchcock Turned the „Crop Duster Attack” into a Cinematic Icon | „North by Northwest”11 (2018). Ich autor, użytkownik podpisujący się jako "CinemaTaylor", jak mało który twórca podobnych audiowizualnych studiów nie tylko swobodnie porusza się po historii kina, ale też umiejętnie potrafi wpleść w wizualną tkankę cytaty z artykułów, książek, Wikipedii, scenariusza filmu czy storyboardów przygotowanych na potrzeby realizacji dzieła z 1959 roku. W przybliżeniu kulis realizacji filmu pomocne były wywiady oraz często przez autora cytowana publikacja Hitchcock at Work Billa Krohna. Wideoeseje CinemaTaylora na swój sposób można potraktować jako (wzbogacone o odniesienia do innych źródeł) audiowizualną adaptację idei, jaka przyświecała Krohnowi, by możliwie najbardziej dogłębnie scharakteryzować przebieg powstania Północy, północnego zachodu.

39 Zob. https://www.youtube.com/watch?v=VZYLzwfWxNw [dostęp 15.01. 2020].

40 Zob. https://www.youtube.com/watch?v=lltazliRp58 [dostęp 15.01.2020].

${ }_{41}$ Zob. https://www.youtube.com/watch?v=DS8swCK8jq4 [dostęp 15.01.2020]. 
Za bodaj najdłuższą pracę należy uznać przeszło czterdziestominutowy Alfred Hitchcock - The Dark Ages ${ }^{42}$ (2018). Ten zrealizowany w pojedynkę projekt, przygotowany przez użytkownika prowadzącego niezależny i mało znany kanał Eyebrow Cinema, ma na celu charakterystykę ostatniego, schyłkowego okresu twórczości Hitchcocka, który zainicjowany został premierą Marnie (1964). Choć w wideoeseju użytkownik odnosi się do całej twórczości brytyjskiego reżysera (pierwsze 12 minut zostało poświęcone filmom sprzed 1963 roku), to nade wszystko interesuje go to, co sam określa jako "mroczne czasy”, a więc okres od połowy lat 60. do 1976 roku, kiedy to na ekranach kin pojawiła się Intryga rodzinna. Autor nie tylko przybliża kulisy realizacji powstałych wówczas filmów, ale też sugeruje, skąd mogła wynikać ich niedoskonałość, mająca w dużym stopniu związek z przemianami społeczno-obyczajowymi, próbami kręcenia przez Hitchcocka filmów tematycznie odległych od jego zainteresowań (vide odnosząca się do zimnej wojny Rozdarta kurtyna [Torn Courtain, 1966]) oraz brak wybitnych współpracowników. Ostatecznie prowadzący Eyebrow Cinema przyznaje, że oglądanie nawet słabszych dokonań brytyjskiego reżysera może być zajęciem fascynującym, bo, przy odpowiedniej optyce, wzbogacającym wiedzę na temat przemian w Hollywood.

\section{W STRONĘ REMIKSU}

Na ostatnią grupę wideoesejów składają się dzieła eksperymentalne - celem autorów tych filmów nie jest ani zwrócenie uwagi na kontekst produkcji, ani gruntowna analiza dzieła pod wybranym kątem, ani też opis wpływu twórczości Hitchcocka na rozwój kina i innych twórców. $\mathrm{O}$ wiele większy nacisk kładą oni na sieć skojarzeń, paradoksalne i komiczne zestawienia oraz zabawę formą. Za prekursorską pracę można tu uznać dzieło z początku wieku, 24 Second Psycho ${ }^{43}$ (2002) Daniela Martinico - żartobliwą wideoinstalację nawiązującą do pracy Douglasa Gordona Twenty Four Hour Psycho z 1993 roku, w której artysta wyświetlał Psychozę w na tyle zwolnionym tempie (dwie klatki na sekundę), że seans wydłużał się do doby. U Martinico z kolei oglądamy skompresowaną do 24 sekund wersję Psychola Gusa Van Santa -

${ }^{42}$ Zob. https://www.youtube.com/watch?v=s2slAVLjxgY [dostęp 15.01.2020].

${ }_{43}$ Zob. http://www.neglectedtransformer.com/martinico/new/24sechigh.mov [dostęp 10.02.2020]. 
trwającą zapewne tyle czasu, ile, zdaniem autora, należałoby poświęcić temu kontrowersyjnemu remake'owi.

Na kondensacji metrażu opiera się także Rear Window Timelapse, opublikowany w 2012 roku przez Jeffa Desoma ${ }^{44}$. W nawiązującym do Okna na podwórze wideo twórca dokonał następującego eksperymentu: wyciął ujęcia przedstawiające kolejne okna i w planie totalnym - umożliwiającym zobaczenie całego podwórza - ukazał, prezentowaną w przyspieszeniu (dzięki poklatkowej technice time-lapse), akcję filmu, zagęszczonego tu do trwającej trzy minuty krótkometrażówki.

Za jeden z ciekawszych wideoeseistycznych remiksów - dzieł, w których połączono fragmenty różnych utworów w nową, integralną całość - można uznać It's A Wonderful Hitchcock ${ }^{45}$ (2017) Philipa Brubakera. Autor powiązał ze sobą wybrane sceny z Tego wspaniałego życia (It's a Wonderful Life, 1946) Franka Capry z muzyką pochodzącą z Zawrotu głowy, co dało wywrotowy efekt - przynajmniej dla widzów znających oba filmy. Świąteczne arcydzieło Capry w reinterpretacji Brubakera przeobraziło się w utwór portretujący postać zagubionego schizofrenika, który sukcesywnie traci kontakt ze światem.

Jeszcze dalej poszedł David Scanlon, który w Second Time's the Charm (A Rebecca Sitcom Intro) ${ }^{46}$ (2019) zmontował wybrane sceny z Rebeki w sitcomową czołówkę, charakterystyczną dla telewizyjnych produkcji lat 80 . By wzmocnić humorystyczny efekt - wynikający niewątpliwie z faktu, że przemontowany film z pewnością trudno byłoby w jakikolwiek sposób skojarzyć z dziełem komediowym - Scanlon w swoim wideoeseju wykorzystał muzykę z czołówki amerykańskiego serialu Who's the Boss (1984-1992) oraz dobrał odpowiedni font do napisów informujących o twórcach sitcomu ${ }^{47}$.

Za oryginalny komentarz do filmu Hitchcocka można także potraktować Rear Window's Runway ${ }^{48}$ (2019) Luisa Mendonki. Autor wziął na warsztat sceny z Okna na podwórze, w których oglądamy zjawiskowo ubraną Grace Kelly, i opatrzył wideo komentarzem pochodzącym z telewizyjnej relacji

\footnotetext{
${ }_{44}$ Zob. https://vimeo.com/37120554 [dostęp 10.02.2020].

45 Zob. https://vimeo.com/248692592 [dostęp 10.02.2020].

46 Zob. https://vimeo.com/363076633 [dostęp 10.02.2020].

47 Pod koniec niespełna minutowego klipu pojawia się literówka - z napisów można wyczytać, że serial został wyprodukowany przez „Davida O. Selznica”.

48 Zob. https://vimeo.com/337528450 [dostęp 10.02.2020].
} 
z pokazu mody, co skądinąd uwypukliło znaczenie kostiumów w filmie Hitchcocka, w którym Lisa Carol Fremont przez większość akcji usiłuje zwrócić na siebie uwagę przejętego śledztwem Jefferiesa.

$\mathrm{Na}$ bardzo ciekawy trop wskazuje Ariel Avissar w Mashup of the Afternoon ${ }^{49}$ (2018), wideoeseju zestawiającym ujęcia pochodzące z Sieci popotudnia (Meshes of the Afternoon, 1943) Mai Deren ze scenami z Psychozy. Wydawałoby się, że porównanie aspektów wizualnych obu dzieł mogłoby prowadzić na interpretacyjne manowce, jednak Avissarowi udaje się w sposób przekonujący pokazać, w jak wielkim stopniu poszczególne ujęcia Psychozy inscenizacyjnie przypominają fragmenty awangardowego klasyka. W żadnym innym wideoeseju ostatnich lat nie udało się tak sugestywnie udowodnić estetyczną korespondencję tak odległych pod względem narracyjnym utworów.

\section{AUDIOWIZUALNY HOMMAGE DLA HITCHCOCKA}

Wysnuwanie wniosków na podstawie wspominanych wideoesejów może wydać się ryzykowne - w dużym stopniu mamy do czynienia z nową tendencją, zjawiskiem, które wciąż się rozwija i każdego roku wzbogacane jest o kolejne inspirujące filmy publikowane w Internecie. Dość zauważyć, że większość wspomnianych przeze mnie prac pochodzi z lat 2014-2019, z czego dziesięć powstało w 2017 roku, zaś w 2016 i 2018 roku można było zobaczyć po osiem nowych wideoesejów - a i te dane nie są precyzyjnie ze względu na niepewność co do rzeczywistej liczby filmików, jakie w tych latach mogły się pojawić.

Pomijając różnorodność podjętych przez użytkowników tematów (związanych oczywiście z postacią i twórczością Hitchcocka), warto też wskazać te aspekty, które łączą poszczególne dzieła. Nade wszystko opisując filmy brytyjskiego twórcy, wideoeseiści przyjmują perspektywę autorską. W niemal każdym wideoeseju - a przynamniej wśród tych, w których warstwę obrazową uzupełniono o odczytywaną „z offu” narrację - mówi się o „filmach Hitchcocka” z pominięciem działalności pozostałych realizatorów (jeśli już jest mowa o innych twórcach, to ewentualnie wspomina się aktorów). Za wyjątek można uznać jedynie Alfred Hitchcock - The Dark

${ }^{49}$ Zob. https://vimeo.com/304454199 [dostęp 10.02.2020]. 
Ages, którego autor zwraca uwagę na regres jakościowy w twórczości Brytyjczyka, spowodowany, między innymi, zakończeniem współpracy z wybitnymi współpracownikami (operator Robert Burke i kompozytor Bernard Herrmann) lub ich śmiercią (montażysta George Tomasini). Inaczej w pozostałych wideoesejach: Mr Nerdista w ROPE: How Alfred Hitchcock Changed Editing Forever co prawda zachwyca się montażem Sznura, ale ani razu nie wspomina nazwiska montażysty, Williama H. Zieglera. Neo, twórca Vertigo - A Look at Color in Film, w swojej analizie Zawrotu głowy koncentruje się na dobrze kostiumów, scenografii i rekwizytów, ale wymienia jednie Hitchcocka jako osobę odpowiedzialną za swoje dzieło, nie podając informacji o wkładzie kostiumografki Edith Head czy scenografów i dekoratorów wnętrz do filmu: Henry’ego Bumsteada, Hala Pereiry, Sama Comera oraz Franka R. McKelvy'ego.

Położenie nacisku na znaczenie autora filmowego w kontekście gotowego dzieła niewątpliwie ma związek z tym, że twórcy wideoesejów przyjmują określoną perspektywę, dzięki której zwracają uwagę jedynie na zalety dzieł brytyjskiego reżysera, składając mu tym samym hołd. Poza wyróżnionym wyżej „sążnistym” esejem Eyebrow Cinema, traktującym o mniej cenionych filmach Hitchcocka, każdy wideoesej to mała celebracja sztuki autora Psychozy - autora potrafiącego umiejętnie budować napięcie, drobiazgowo inscenizować rozmowy bohaterów, znakomicie charakteryzować portretowanych protagonistów, wreszcie: wzbogacać swoje dzieło w tropy, które poprowadzą do odczytania w kluczu psychoanalitycznym, pozostającym (między innymi dzięki popularności artykułów i książek Žižka) najczęściej obieraną ścieżką interpretacyjną.

Niejednokrotnie - w celu wyraźniejszego zaznaczenia swojego stanowiska - twórcy wideoesejów decydują się na wykorzystanie narracji „z offu”. Niemniej to graficzne ingerencje w klasyczny film robią tu największe wrażenie i poświadczają, jak w twórczy sposób można interpretować dzieła już znakomicie, wydawałoby się, znane kinomanom. Bodaj najlepszym przykładem pozostaje How Alfred Hitchcock Blocks a Scene, precyzyjnie odwzorowujący ruchy postaci dzięki umieszczonej na ekranie grafice. Zwraca także uwagę przekonujące wykorzystywanie materiałów archiwalnych, zwłaszcza sposób, w jaki po nie sięga Cinema Tylor w pracach poświęconych filmowi Północ, północny zachód. Charakterystyczne dla tego rodzaju wideoesejów są także trafnie dobrane cytaty z książek oraz sposób, w jaki autorzy 
je przywołują. Przykładowo: użytkownik kanału Jack’s Movie Reviews w Vertigo Analysis - Love, Identity \& Relationships, cytując fragment książki Danny'ego Peary'ego Crime Movies, nie tylko umieszcza na ekranie okładkę cytowanej publikacji, ale zaraz obok niej - odczytywany przez siebie tekst. Tego rodzaju „wizualne przypisy” dość często pojawiają się w wideoesejach - podobnie też, choć już nie z taką intensywnością, jak umieszczona na ekranie w końcowych partiach filmu bibliografia.

Trzeba przyznać, że Hitchcock jako taki pozostaje wdzięcznym tematem do „wideoopisania”. Chętnie portretowany w piśmiennictwie filmoznawczym, regularnie udzielający się w promocji swoich filmów (vide mnóstwo wywiadów telewizyjnych, których fragmenty zamieszczane są w Internecie) i przede wszystkim tworzący swego czasu niezwykle popularne i wyraziste pod względem artystycznym dzieła - wszystkie te elementy wpłynęły na kinomanów pragnących przedstawiać swoje spostrzeżenia za pomocą obrazu ruchomego, nawet jeśli nie są wykształconymi montażystami. Z tym ostatnim wiąże się bodaj największa zaleta płynąca z umieszczania w Internecie wideoesejów - powszechny dostęp użytkowników do treści. Opisywane wyżej audiowizualne szkice - a także te, które dopiero powstaną - umożliwiają odbiorcom łatwe dotarcie do treści odsłaniających znaczenia filmów sprzed pół wieku. Nie sposób nie zwrócić na to uwagi, myśląc o popularyzacji twórczości Alfreda Hitchcocka.

\section{Bibliografia}

Marcin Adamczak, Konstruując Alfredów Hitchcocków, „Kwartalnik Filmowy” 2009, nr 67-68.

Nora M. Alter, The Essay Film After Fact and Fiction, Columbia University Press, New York 2018.

Paweł Biliński, Palimpsesty. Wideoeseistyka Kevina B. Lee, „EKRANy” 2016, nr 5 (33).

Jean Burgess, Joshua Green, Przedsiębiorczy Vloger: kultura uczestnictwa poza podziałem na profesjonalistów i amatorów, tłum. D. Rode, [w:] Badanie widowni filmowej. Antologia przekładów, red. K. Klejsa, M. Saryusz-Wolska, WN Scholar, Warszawa 2014.

Timothy Corrigan, The Essay Film: From Montaigne, After Marker, Oxford University Press, New York 2011. 
Essays on the Essay Film, eds. N.M. Alter, T. Corrigan, Columbia University Press, New York 2017.

Christian Keathley, La Caméra-Stylo. Notes on Video Criticism and Cinephilia, $\mathrm{w}$ : The Language and Style of Film Criticism, eds. A. Clayton, A. Klevan, Routledge, London - New York, 2011.

Iwona Kurz, "I got you tube”. Kino a serwis YouTube.com - odmiany kinofilii, [w:] Pogranicza audiowizualności. Parateksty kina, telewizji i nowych mediów, red. A. Gwóźdź, TAiWPN Universitas, Kraków [cop. 2010].

Stanisław Liguziński, Wideoesej. Zapiski na marginesach, „EKRANy” 2012, nr 6 (10). Grażyna Świętochowska, Wideoesej, czyli od Chrisa Markera do Fandoru. Historia awansu pewnej formy audiowizualnej wyrosłej z kinofilii, „Kwartalnik Filmowy" 2018, nr 104.

François Truffaut, Hitchcock / Truffaut, współpraca H. Scott, tłum., oprac. i posłowie T. Lubelski, „Świat Literacki”, Izabelin 2005.

\section{Źródła internetowe}

„Audiovisualcy. An Online Forum forl Videographic Film Studies”, https://vimeo. com/groups/audiovisualcy.

Ariel Avissar, Mashup of the Afternoon, https://vimeo.com/304454199.

Ariel Avissar, Will DiGravio, Grace Lee, The Best Video Essays of 2019, https:// www.bfi.org.uk/news-opinion/sight-sound-magazine/polls-surveys/ best-video-essays-2019.

Mackenzie Bell, Psycho and The Duality of Man (Video Essay), https://www.youtube. $\mathrm{com} /$ watch? $\mathrm{v}=$ UNACtHIeX-o.

Steven Benedict, The Hitchcock Gallery, https://vimeo.com/115718613.

Blog Is This Just Fantasy?, https://plainflavoredenglish.com.

Philip Brubaker, It's A Wonderful Hitchcock, https://vimeo.com/248692592.

CinemaTyler, The Bizarre Process of Writing 'North by Northwest'| Screenwriting, https://www.youtube.com/watch?v=lltazliRp58.

CinemaTyler, How Hitchcock Turned the 'Crop Duster Attack' into a Cinematic Icon | North by Northwest, https://www.youtube.com/watch?v=DS8swCK8jq4. Jeff Desom, Rear Window Timelapse, https://vimeo.com/37120554.

The Discarded Image, Psycho - How Alfred Hitchcock Manipulates An Audience, https://www.youtube.com/watch?v=xm-9E275D9c.

Matt Draper, Rear Window - Turning Viewer into Voyeur, https://www.youtube. $\mathrm{com} /$ watch? $\mathrm{v}=2 \mathrm{UH} 10 \mathrm{Mm}-6 \mathrm{tE}$. 
Entertain the Elk, How Hitchcock Creates Suspense, https://www.youtube.com/ watch?v=s-QVHJDmD6A.

Eyebrow Cinema, Alfred Hitchcock - The Dark Ages, https://www.youtube.com/ watch? $\mathrm{v}=\mathrm{s} 2 \mathrm{slAVLjxgY}$.

Peet Gelderblom, Hitchcock \& De Palma Split Screen Bloodbath, https://vimeo. com/193068848.

Margarita Georgitseas, Understanding Psycho: The Uncanny, https://www.youtube. com/watch? $\mathrm{v}=$ _FMkGEZP3w0.

John Gibbs, Douglas Pye, Opening choices - Notorious, https://vimeo.com/185350060. Jack's Movie Reviews, Rear Window - Hitchcock's Manipulation, https://www. youtube.com/watch?v=e4Yw8hz3tG8.

Jack's Movie Reviews, Vertigo Analysis - Love, Identity \& Relationships, https:// www.youtube.com/watch? $\mathrm{v}=\mathrm{XjNZUXMsrgA}$.

kogonada, Eyes of Hitchcock, https://vimeo.com/107270525.

Daniel Martinico, 24 Second Psycho, http://www.neglectedtransformer.com/martinico/new/24sechigh.mov.

Luis Mendonca, Rear Window's Runway, https://vimeo.com/337528450.

A Million Movies, Strangers On a Train: The Doubles Motif, https://www.youtube. $\mathrm{com} / \mathrm{watch}$ ? $\mathrm{v}=\mathrm{MW}-\mathrm{IWM} 5 \mathrm{CoQ} 4$.

neo, Vertigo - A Look at Color in Film, https://www.youtube.com/watch?v= scmHVYYZZ3w.

Mr Nerdista, ROPE: How Alfred Hitchcock Changed Editing Forever, https://www. youtube.com/watch? $\mathrm{v}=\mathrm{W} 8 \mathrm{R} 5 \mathrm{Kd} 4 \mathrm{NWKM}$.

Nerdwriterl, How Alfred Hitchcock Blocks A Scene, https://www.youtube.com/ watch? $\mathrm{v}=\mathrm{UgnNakO6JZw}$.

Matt Novak, Hitchcock's Hands, https://vimeo.com/230194725.

Morgan T. Rhys, Every Alfred Hitchcock Cameo, https://www.youtube.com/ watch? $=$ =_YbaOkiMiRQ.

One Hundred Years of Cinema, 1940: Rebecca - Hitchcock's obsessions... Love, Violence, and the Psycho-sexual, https://www.youtube.com/ watch?v=VZYLzwfWxNw.

Brais Romero, Hitchcock | Truffaut, https://vimeo.com/160927998.

Jorge Luengo Ruiz, Alfred Hitchcock // Point of View, https://vimeo.com/211361198.

Jorge Luengo Ruiz, Alfred Hitchcock's Close-Ups, https://vimeo.com/137761623.

Bill Rwehera, The Hitchcock Trademark No One Talks About, https://www.youtube. com/watch?v=JVoiI-wCNm8. 
Bill Rwehera, The Many Genres of Rear Window, https://vimeo.com/229591018.

David Scanlon, Second Time's the Charm (A Rebecca Sitcom Intro), https://vimeo. com/363076633.

Leigh Singer, Psycho vs Psycho. Alfred Hitchcock's Original vs Gus Van Sant's Remake, https://www.youtube.com/watch?v=xI_4LT7BTm4\&feature=emb_logo.

Jacob T. Swinney, The Influence of 'Vertigo', https://www.youtube.com/ watch? $\mathrm{v}=\mathrm{F} 3 \mathrm{WHuOcwyUs}$.

This Guy Edits, 3 Hitchcock Techniques We Shoul Copy More, https://www.youtube. com/watch?v=E1LzhiCcOY0.

Max Tohline, Alfred Hitchcock's 39 Stairs [2 loops], https://vimeo.com/239872105. Trailer filmu Psychoza, https://www.youtube.com/watch?v=AJdPFYENJBo.

\section{Audiovisual Vertigo. Alfred Hitchcock and Video Essays}

The article focuses on paratexts that refer to the work of Alfred Hitchcock. The author focuses on video essays, which either describe, analyze and interpret films made by the director of Vertigo, or to highlight specific themes that are characteristic of his films. The author briefly examines video essays as a new way of 'writing' about the cinema, and draws attention to the popularity of YouTube and Vimeo platforms, commonly used by vloggers to share materials they have edited. The next parts of the article are devoted to video essays thematically focused on Hitchcock and his work. By systematizing the issue and pointing out the most important components of video essays, the author distinguishes the following types of such short films: those that focus on specific themes in Hitchcock's films; those regarding the director's method; those examining the influence of his films; those analyzing specific films from different perspectives; those that read Hitchcock's films in a historical perspective; and finally various video remixes based on the assembly of excerpts of Hitchcock's works with shots from other films.

Keywords: Hitchcock, video essay, paratext, YouTube, Vimeo, remix 